\title{
THE ASSOCIATION OF COCCIDAE.
}

\author{
BY GEO. B. KING, LAWRENCE, MASS.
}

The present paper is intended to give a list of such Coccidae as are known to the writer from published or unpublished records to have been found associated together on the same food plant, or in ants' nests, etc. Incomplete as it must be, it will show to some extent the difficulty which accompanies the identification of species of the same genus so found, these being often closely allied.

Furthermore it will be seen how difficult it is to treat the infested plants with insecticides, for as a matter of fact in some instances, the treatment for one would not do for the other, therefore various means have to be adopted.

It has been asked in the writers hearing many times "are varieties produced by the association of two or more species living together on the same food plant." Such questions are usually asked by individuals who having read somewhat superficially the writings of popular authors upon evolution and general biology assume a more perfect knowledge than the entomologist who has made such investigations the study of his life.

So far as I know no varieties have been found in the Coccidae, which could be said to have been the result of two or more species living together.

There are however means whereby this could be proved, provided one had the time to devote to it, and the results would no doubt be of much value to science.

I well remember many years ago while in conversation with Dr. Hagen then at Harvard, what he said to me when I asked him if in his opinion there were any new species of recent origin. His reply was "you will not live long enough to find one." We, of course, are constantly finding and describing new species and varieties; but these we believe have been in existence for a long time but only of recent discovery and are more frequently found in localities which have been little worked up. It would indeed be of much interest if some one would try to find whether or not a male coccid would mate with a female not of its own kin.

The following citations for the most part are records made by Prof. Cockerell although several are from various authors including myself. Some appear here for the first time.

Lecanium pseudhesperidum Ckll. and Diaspis boisduvalii Sign. Associated together on Cattleya in a greenhouse at Ottawa Canada. The later species $D$. boisduvalii has hitherto been placed in the genus Aulacispis. Prof. Cockerell writes me that Mr. Newstead shows that it should be placed in the Diaspis.

Lecanum hesperidum L. Pulvinaria flocifera West (P. brassiae) and Hemichionaspis aspidistrae Sign. Cited as 
Chionaspis braziliensis Sign. are found together on leaves of an orchid in Trinidad.

Lecanium hesperidum L. and a Pulvinaria sp. on leaves of "fitoloca" at Monterey, Mexico.

Lecanium baccharidis Ckll. and Mytilaspis perlonga Ckll. on twigs and branches of Baccharis at Campinas, Brazil.

Lecanium longulum Dougl. and $L$. melaleucae Mask. on leaves of Monstera deliciosa in the Harvard botanical greenhouse at Cambridge, Mass.

Lecanium sp. Ceraplastes sp. young of Aspidiotus articulatus Marg. and $A$. personatus Comst. on leaves of Anacardium occidentalis at Kingston, Jamaica.

Lecanium sp. Ceroplastes floridensis Comst. and Parlatoria sp. on Anthurium lanceolatum at Kingston, Jamaica.

Lecanium mangiferae Green and Vinsonia stellifera Westw. on leaves of Bambosa malaccencis at Kingston, Jamaica.

Lecanium mangiferae Green. Saissetia oleae Bern. Ceroplastes floridensis Comst. Vinsonia stellifera Westw. and Aspidiotus personatus Comst. on leaves of Mango in Manchester square, Kingston, Jamaica.

Lecanium hesperidum L. and Saissetia oleae Bern. on Hippeastrum equestre at Kingston, Jamaica.

Eulecanium quercitronis Fitch and Chionaspis americana Johns on Ulmus americana at Springfield, Mass.

Eulecanium caryae Fitch and what I take to be $E$. perscae Fabr. on a peach tree at Niagara, Ontario, Canada.

Saissetia oleae Bern. Ceroplastes floridensis Comst. and C. cirripediformis
Comst. on Lignum vitae tree at Kingston, Jamaica. Saissetia hemisphaerica Targ. and Orthezia insignis Dougl. on Chrysanthemums at Kingston, Jamaica.

Saissetia hemisphaerica Targ. and Dactylopius longispinus Targ. on house fern at Las Cruces, New Mexico.

Saissetia coffeae? Walk. and Ceroplastes myricae L. in Assam India on tea. $S$. coffeae may yet be found to be a valid species. I received an adult female scale on leaf of coffee from Mr. Adolph Hempel of Brazil. The scale seems different from those of $S$. hemisphaerica and $S$. filicum but more material must be obtained before a decision can be made.

Saissetia hemisphaerica Targ. and Aspidiotus aurantii Mack on Areca catechu grown in pots at Cavalieris Penn., Jamaica.

Saissetia hemisphaerica Targ. Diaspis zamice Morgan (this is recorded as Aulacaspis elegans Leon but Mr. Newstead shows it to belong to the Diaspis Cockerell in litt.) and Dactylopius longispinus Targ. on Cycas revoluta under glass at Springfield, Massachusetts.

Ceroplastes myricae L. and Fiorinia theae? on tea plant in Assam, India.

Ceroplastes irregularis and Phenacoccus simplex King, on Atriplex confertifolia and $A$. polycarpa? at Lone Pine, California. Icerya rosae and Ceroplastes depressus Ckll. found under bark of Lignum vitae tree at Kingston, Jamaica.

Icerya montserratensis and Ischnaspis longirostris. Sign on a palm in Trinidad.

Aclerda japonica Newst. and Antonina socialis Newst. under the leaf sheath of 
Arundinaria japonica under glass, Broxhourne Herth, England.

Ripersia flavola Ckll. and R. candidata King, in ants nests in Massachusetts. Aspidiotus articulatus Morg. Mytilaspis becki Newm. and Chionaspis citri Comst., on leaves of lime in Trinidad.

Aspidiotus articulatus Morg. and Chrysomphalus aonidum L. on orange at Tampico, Mexico.

Aspidiotus yuccarum Ckll. and Dactylopius dasylirii Ckll. at the base of leaves of Yucca elata at Mesilla Park, N. M.

Aspidiotus ancylus Putn. and $A$. fernaldi Ckll. on Gleditschia triacanthos in Charlesbank Park, Mass.

Aspidiotus hederae Vall. and Diaspis zamiae Morgan, on Cycas revnluta in a greenhouse at Lawrence, Mass.

Aspidiotus personatus Comst. and Howsardia biclavis Comst. on the skin of orange (fruit) from Colima, Mexico, quarantined at San Francisco, California. Aspidiotus cryptoanthus and Asterolecanium variolosum Ratz. var japonicum Ckll. on Quercus glandulifera from Japan.

Aspidiotus orientalis Newst and Ceroplastes myricae L. on Cycas revoluta in Assam, India.

Aspidiotus candidulus Ckll. and Xerophilaspis prosopidis on leaves and twigs of Prosobis velutina at Tuscon, Arizona.

Aspidiotus forbesi Johns and $A$. ancylus Putn. on crab apple and plum in Kansas.

Aspidiotus aurantii Mask. and Asterolecanium variolosum Ratz recorded as a Planchonia on oak at Sidney, New South Wales.
Aspidiotus personatus Comst. and Chrysomphalus aonidum L. on leaves of Anacardium occidentale at Kingston, Jamaica.

Aspidiotus aurantii Mask. and Chrysomphalus aonidum L. on Areca catechu grown in pots at Cavalieris Pen., Jamaica.

Aspidiotus articulatus Morg. and Ceroplastes floridensis Comst. on leaves of Brunfelsia americana at Kingston, Jamaica.

Aspidiotus articulatus Morg. and $A$. personatus Comst. on Cassia fistula at Kingston, Jamaica.

Aspidiotus articulatus Morg. A. personatus Comst. Pulvinaria cupaniae Ckll. and Diaspis or Chionaspis sp. on leaves of Chrysophyllum cainito in Manchester Square, Kingston, Jamaica.

Aspidiotus articulatus Morg. A. personatus Comst. Chrysomphalus aonidum L. and Ceroplastes floridensis Comst. on Ficus tree in the yard of the Museum at Kingston, Jamaica. All of the four species cited were also found on a young banana tree out of doors in Jamaica.

Aspidiotus articulatus Morg. A. personatus Comst. and Vinsonia stellifera Westw. on leaves of Mangifera indica at Kingston, Jamaica.

Aspidiotus sp. and Dactylopius longispinus Targ. on green mangoes at Kingston, Jamaica.

Aspidiotus articulatus Morg. A. per. sonatus Comst. and Chrysomphalus aonidum L. on leaves of Nerium oleander at Kingston, Jamaica.

Aspidiotus articulatus Morg. and $A$. 
personatus Comst. on leaves of Olea hispanica in the Parade garden in Jamaica and the same species on leaves of Persea, also on leaves of Punica granatum, Aralia guilfoylei, and Aperba tibourbou in Jamaica. The same species together with Asterolecanium (olim Asterodiaspis pustulans Ckll. on leaves of Capania edulis at Kingston Jamaica. The same Aspidiotus on Guaiacum officinola and on leaves of Erythrina umbrosa with Ceroplastes floridensis Comst., at Kingston, Jamaica. The same three species were found on Melicocca bijuga in Jamaica.

Aspidiotus articulatus Morg. Chrysomphalus aonidum L. and Pulvinaria capaniae Ckll. on Bignonia magnifica in Jamaica.

Aspidiotus personatus Comst. A. articulatus Morg. and Chrysomphalus aonidum L. on Jasminum pubescens and

$A$. personatus and $A$. articulatus on Lawsonia inermis and Therletia neriifolia at Kingston, Jamaica.

Diaspis arizonicus Ckll. and Xerophilaspis prosopidis Ckll. on leaves and branches on Prosopis velutina, Wooton near Kellners Ranch several miles west of Phoenix, Arizona.

Diaspis celtidis Ckll. and Pulvinaria innumerabilis Rathv. on Celtis at San Antonio, Texas.

Mytilaspis glonveri Pack, Chionaspis citri Comst. and Chrysomphalus aoni- $\operatorname{dum} \mathrm{L}$. on leaves and fruit of orange at Tampico, Mexico.

Mytilaspis bambusicola Ckll. and Asterolecanium bambusae Boisd. on stems of bamboo at Campinas, Brazil.

Mytilaspis concolor Ckll. and Solenophora coloradensis Ckll. at Canon City, Colorado on twigs and stems of Atriplex canescens.

Mytilaspis ulmi L. Chionaspis furfurus Fitch and Phenacoccus dearnessi King, on an old hawthorn tree at London, Ontario, Canada.

Mytilaspis ulmi L. and Asterolecanium variolosum Ratz on oak twigs from Germany.

Mytilaspis becki Newm. and Aspidiotus articulatus Morg. on twigs of Murraya at Kingston, Jamaica.

Addenda by Professor Cockerell.

On a single guava (Psidium) tree at Kingston, Jamaica, I found

Saissetia oleae. Pulvinaria cupaniae

" hemisphaerica. Vinsonia stellifera Aspidiotus articulatus. Chrysomphalus aonidum

Aspidiotus personatus. Ceroplastes floridensis.

Ripersia fimbriatula and $R$. conpusella together in nests of Lasius at Las Vegas, N. M. 

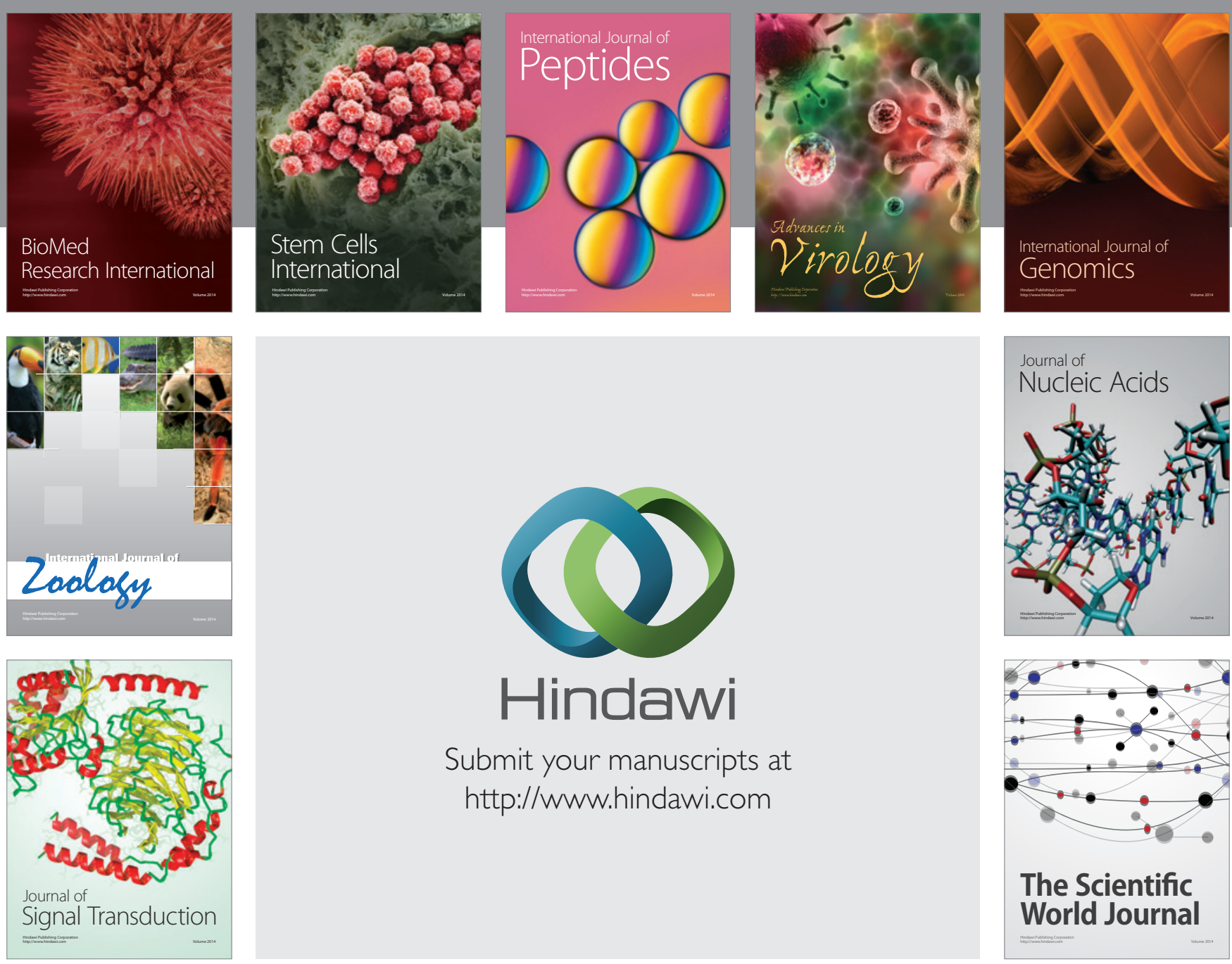

Submit your manuscripts at

http://www.hindawi.com
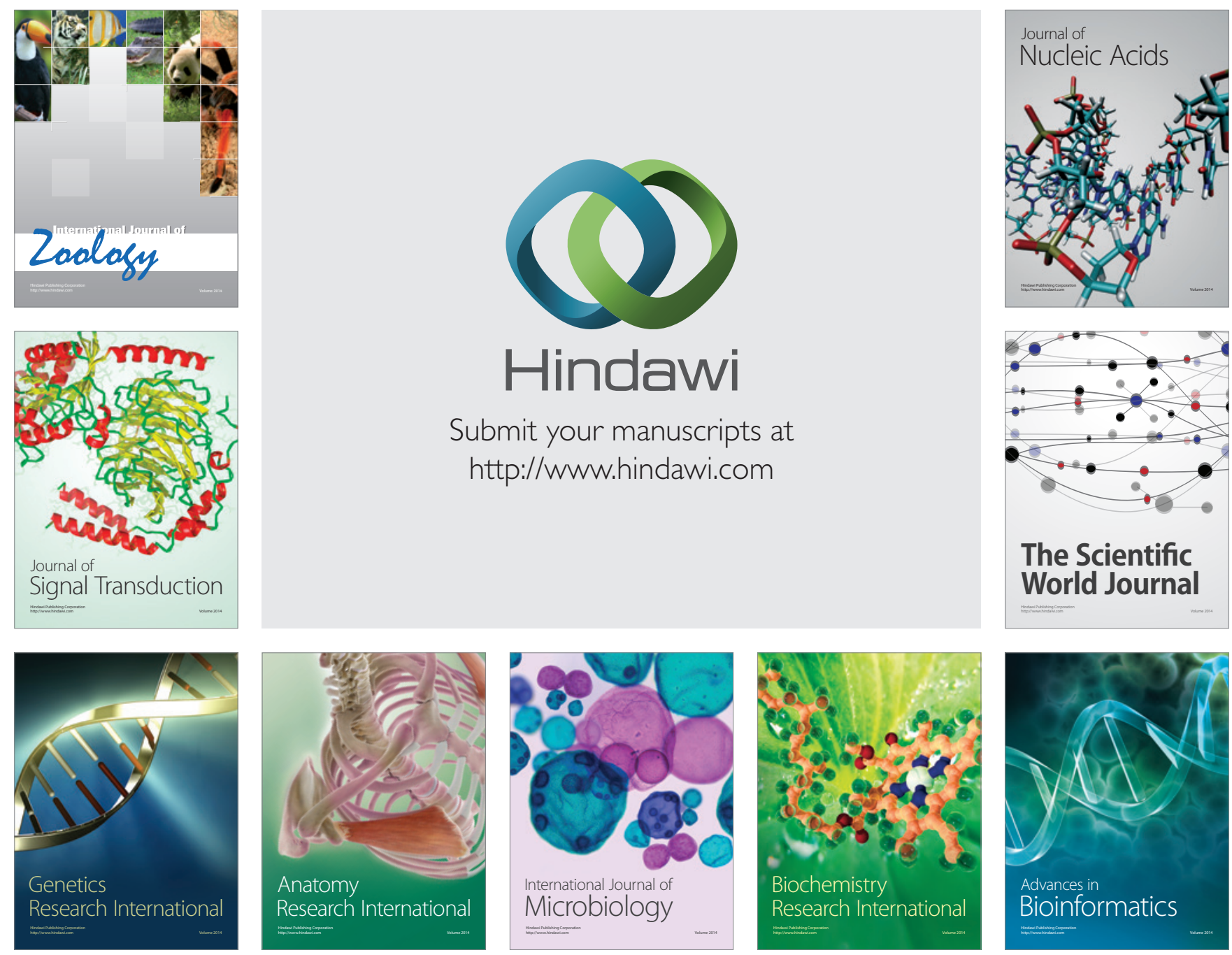

The Scientific World Journal
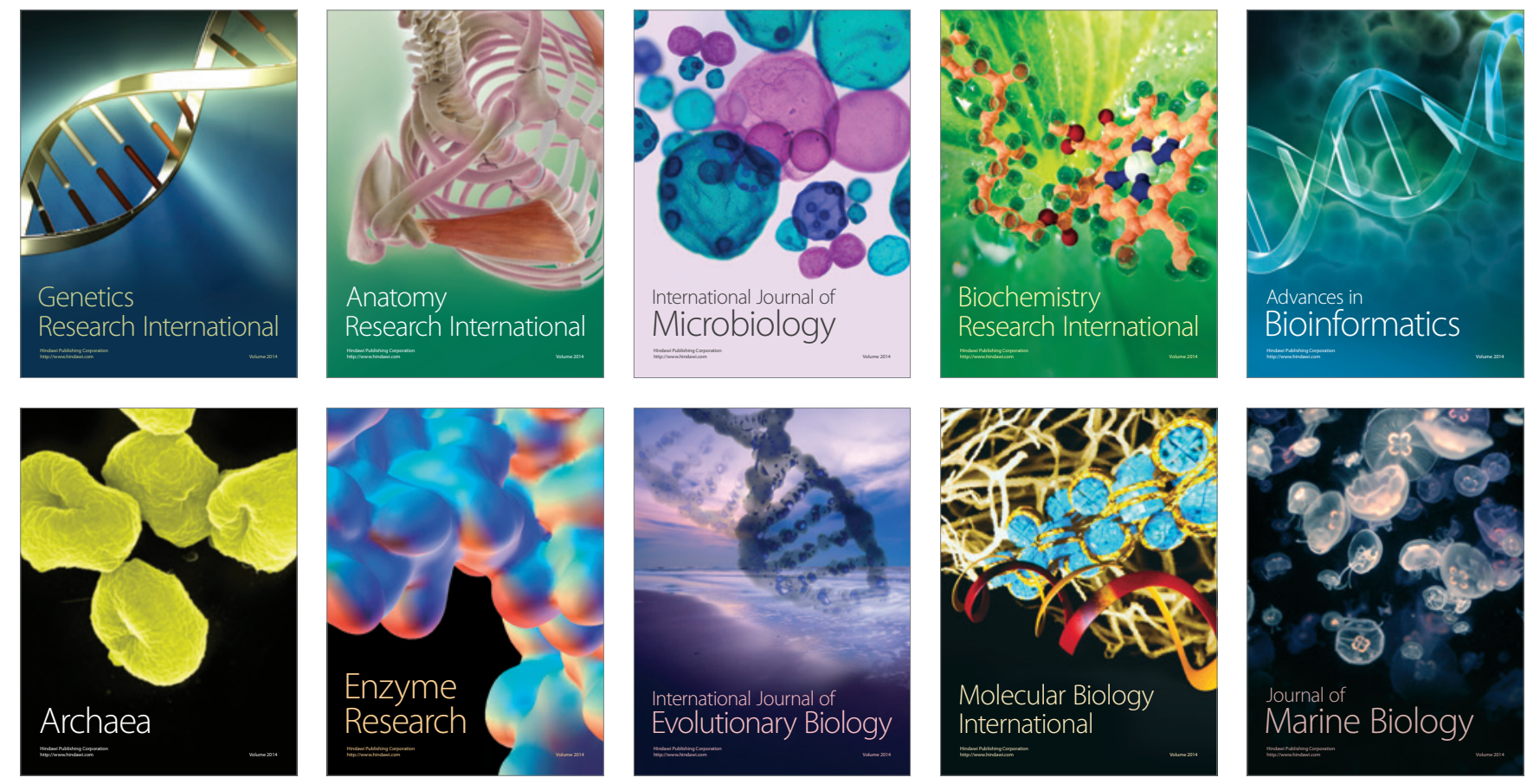